\title{
CORPUS ANALYSIS OF HIGH SCHOOL LEARNERS' RESEARCH PAPERS IN HEALTH SCIENCE (2016-2019)
}

\author{
Anita Pastare \\ Rīga Stradin̄š University, Latvia \\ Aira Aija Krūmiña \\ Rīga Stradinš University, Latvia \\ Miervaldis Karulis \\ Rīga Stradiņš University, Latvia
}

\begin{abstract}
In Latvia, the learners of secondary school as a requirement gets acquainted with basics of research - selection of literature, data collection and processing, communication and presentation skills.

The present article deals with an analysis of the themes and texts (corpus) of the research papers (RP) in Health Science worked out by the authors of the top-ranked RP presented in the Scientific Conference of High School Learners of Latvia from 2016 to 2019. A logical inductive content analysis of features specific to each $R P$, and sequential categorization and grouping into a higher level of components were performed. The quantitative data were processed by using AntConc, IBM SPSS Statistics 22 and Microsoft Excel software.

The aim of the research was to find out the themes and content variations of $R P$, and the characteristics of the language - tokens, types and keywords.

The results show that there is a thematic uniformity in RP. The statistical characteristics of language differ in terms of lexical diversity and the frequency of keywords and their collocations. Mostly individual keywords dominate.

The results obtained can be used to develop recommendations for learners and teachers as a model for theme selection, presentation of research and criteria for evaluating $R P$.
\end{abstract}

Keywords: components, corpus, Health Science, high school learners' research, themes, tokens, types.

\section{Introduction}

The need to develop research at the secondary school level in Latvia has been identified as one of the indicators of general secondary education. Owing to successfully elaborated research work, the high school learner has mastered certain basics of research work - literature selection, data processing, communication and presentation skills. It is gratifying that in recent years there has been a significant increase in the interest of high school learners of Latvia in 
research into Health Science in particular. If initially, for example, in 2016, there were 23 research papers, then, in 2018, there were already 69 that had already passed a certain quality test at distric and regional conferences. This shows that the today's young person (14/15 - 18 year old) seriously considers about health issues, and is therefore concerned about his/her own health and the health of family members, and is not indifferent to the processes that take place in his/her body, in the environment and society as a whole.

One of the criteria for the evaluation of research papers (hereafter, RP) for the Latvian High School Learners' Scientific Conference is the quality of their written language - a logical presentation of the content of the paper, precise use of terms according to the chosen research theme, lexical diversity, correct use of morphological and syntactic means. For further university studies and research, high school learners will need the ability to lay out a theoretical framework of research in a clear and understandable way, formulate hypotheses and research questions, describe methods, conduct a research analysis and draw conclusions.

Within the framework of the present study, the RP in Health Science submitted to the National Conference in 2016 (23), 2017 (29), 2018 (69) and 2019 (24) were used for the analysis of the language corpus.

The aim of the study was to carry out a study of the content of high school learners' RP, to find general characteristics of RP language corpus - tokens (total word count), types (word type, including derivatives), keywords, their frequency and correlations, and to gather the topics of RP in Health Science, which had been chosen by high school learners.

\section{Discussion}

Nowadays, the language corpus is widely used for a linguistic analysis of authentic written and spoken language, using technological capabilities. The language corpus is a digitized body of text that contains large volumes of text about a particular discourse or language use. Developing a RP for a learner first involves studying and combining different texts into a single coherent (related) narrative that reflects the nature of the topic. In the RP, the learner's task is to write a coherent text (10-20 page long) both in the literature review and in the practical part. Given the opportunities offered by the Internet, finding, researching and evaluating the quality of materials is of great importance. Often, the learner has problems in choosing material in a practically opaque abundance of information without certain selection criteria. At the same time, it is necessary to practice planning a sequential scientific structure, exerting relevant information, narrowing the subject to the desired volume. At this point, the support of the supervisor or the advice of the scientific adviser (Berhman, 2006) plays an important role (Berhman, 2006); deliberate and well-founded university-school 
cooperation has become a necessity in the development of RP (Aizsila, 2012). At the same time, we can talk about the necessity and importance of developing not only research but also literary or linguistic competences of the high school learner, which was studied in more detail in the articles of Latvian and foreign authors, for example, (Skalberga, 2012; Kony \& Rimpelä, 2012; Pace, 2017; Bañez et al., 2019).

Research shows that high school learners rate the school as a place to conduct research projects and develop RP on specific health topics, meaning both healthpromoting school environments (Basch, 2011; Peralta \& Rowling, 2018) and health education issues in the curriculum (Begoray et al., 2009). In turn, specific research in Health Science, as well as its analysis, is one way of studying learners' health literacy from the perspective of learners themselves rather than adults (Stars, 2019). Such studies reveal the subjective experience and views of young people as well as topics young people find relevant, and help to understand whether a young person has been able to evaluate information correctly and assess its reliability (Peralta \& Rowling, 2018) and the way he/she would like not only to receive information about his/her health but also to pass a message on to others.

In the studies (Stars, 2019) that examine adolescents' views on health literacy and health education at school, it was concluded that adolescents would like more information on health topics such as depression, eating disorders, first aid, teenage pregnancy, bioterrorism, alternative lifestyles (vegetarianism, veganism), heredity and genes, how to get health care service, common diseases, including oncological diseases and HIV/AIDS. These are the issues that led them to independently search for and find information and evaluate it (Begoray et al., 2009). At the same time, these are the themes that appear as dominant in RP in the framework of our study.

\section{Methodology}

The initial data set is the texts (corpus) of the RP in Health Science submitted for the National Competition of Latvian high school learners in the period from 2016 to 2019. Using a logical, inductive content analysis by a number of features specific to each RP, there has been developed, in accordance with the current regulatory framework (Ministru kabineta noteikumi, 2013), a typology or components of RP in Health Science, to explore each of these components individually (in depth) as part of a divided whole.

Initially, through the use of the inductive content analysis (Elo \& Kyngäs, 2008), RP were read several times and understood; moving from the specific one read and understood to the general. The process of the inductive content analysis included: open coding - creating codes or descriptive phrases for a selected unit of the analysis; creating of categories - combining meaningful 
codes; grouping - reducing categories into broader and higher level categories (composition elements); generalizing - general desribing of the research topic using categories.

The information about the composition elements was obtained through instrumental methods - the free corpus analysis software AntConc (version 3.5.8), available online, and the statistical data processing software IBM SPSS Statistics 22.

The statistical linguistic tool or text analysis free software AntConc as a digital analysis tool is used for a text anlysis of the usage of words and phrases. The method is based on referring a text item to a set of texts (corpus). For the purpose of this study, the text must be reformatted in the AntConc readable format - from Microsoft Word or pdf to txt in plain-text file format. The texts of all the RP are prepared together (the corpus) in an appropriate format and each $\mathrm{RP}$ (the item or unit of analysis) is analysed separately. By applying each unit of analysis to the corpus, keywords and essential expressions (collocations) were found. Specific, very commonly or rarely used terms were also selected. The number of keywords, collocations and other parameters in the software at the end of processing were obtained as numerical values. The significance of keywords and collocations is illustrated by their specific distribution. For each RP, a specific (unique) word (term) was found. Types of different combinations related to this word mentioned throughout the corpus as a whole were analysed in the present study.

If the logarithmic probability value (p) with Bonferroni correction is $\mathrm{p}<0.01$, the level of significance of the analysis unit is $95 \%$.

From the primary logical analysis of the data and the secondary electronic analysis using Microsoft Excel software, keywords were extracted and selected.

\section{Results and Analysis}

The result of the development of high school lesarners' RP is new data. In 125 RP out of 145 developed from 2016 to 2019 (Table 1A), the authors emphasize the novelty of the data obtained. Most often the practical part of research was carried out in schools - during the period under review there is twice as much research done in schools than in other places (Table 1B).

Of the $145 \mathrm{RP}$, only 30 were developed in laboratories or in out-of-school institutions over a four-year period (Table 1C). Surveys or questionnaires were used as a method to obtain data in almost half of all RP (Table 1D). 
SOCIETY. INTEGRATION. EDUCATION

Proceedings of the International Scientific Conference. Volume III, May $22^{\text {th }}-23^{\text {th }}$, 2020. 424-436

Table 1A Number of RP by years: secondary data used

\begin{tabular}{|ccccc|}
\hline \multirow{4}{*}{ Year } & \multicolumn{3}{l}{} \\
\cline { 2 - 5 } & & \multicolumn{3}{l}{ Secondary data used } \\
\cline { 2 - 5 } & No & Yes & \\
\cline { 2 - 5 } & 2016 & 21 & 2 & 23 \\
\cline { 2 - 5 } & 2017 & 27 & 2 & 29 \\
\cline { 2 - 5 } & 2018 & 60 & 9 & 69 \\
\cline { 2 - 5 } & 2019 & 17 & 7 & 24 \\
\hline & Total & $\mathbf{1 2 5}$ & $\mathbf{2 0}$ & $\mathbf{1 4 5}$ \\
\hline
\end{tabular}

Table 1C Number of RP by years: practical part carried out in laboratories

\begin{tabular}{|crrrr|}
\hline \multirow{4}{*}{ Year } & & \multicolumn{2}{c}{ Laboratories } & \multirow{2}{*}{ Total } \\
\cline { 2 - 4 } & & No & Yes & \\
\cline { 2 - 4 } & 2016 & 18 & 5 & 23 \\
\cline { 2 - 4 } & 2017 & 23 & 6 & 29 \\
\cline { 2 - 4 } & 2018 & 60 & 9 & 69 \\
\cline { 2 - 4 } & 2019 & 14 & 10 & 24 \\
\cline { 2 - 4 } & Total & $\mathbf{1 1 5}$ & $\mathbf{3 0}$ & $\mathbf{1 4 5}$ \\
\hline
\end{tabular}

Table 1B Number of RP by years: practical part carried out in schools

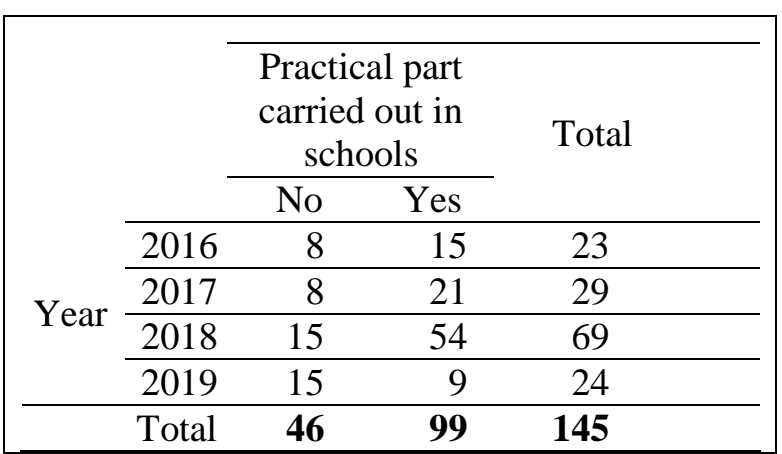

Table 1D Number of RP by years: surveys Used

\begin{tabular}{|c|c|c|c|c|}
\hline & & \multicolumn{2}{|c|}{ Surveys } & \multirow{2}{*}{ Total } \\
\hline & & No & Yes & \\
\hline \multirow{5}{*}{ Year } & 2016 & 10 & 13 & 23 \\
\hline & 2017 & 14 & 15 & 29 \\
\hline & 2018 & 29 & 40 & 69 \\
\hline & 2019 & 17 & 7 & 24 \\
\hline & Total & 70 & 75 & 145 \\
\hline
\end{tabular}

The data acquisition during interviews was twice as rare as surveys (75 surveys (Table 1D) and 37 interviews (Table 1E)). Consultants were available for 58 RP developers (Table 1F).

Table 1E Number of RP by years: interviews used

\begin{tabular}{|crrrr|}
\hline \multirow{4}{*}{ Year } & & \multicolumn{2}{c}{ Interviews } & \multirow{2}{*}{ Total } \\
\cline { 2 - 4 } & 2016 & No & Yes & \\
\cline { 2 - 4 } & 2017 & 25 & 9 & 23 \\
\cline { 2 - 4 } & 2018 & 50 & 4 & 29 \\
\cline { 2 - 4 } & 2019 & 19 & 5 & 24 \\
\hline & Total & $\mathbf{1 0 8}$ & $\mathbf{3 7}$ & $\mathbf{1 4 5}$ \\
\hline
\end{tabular}

Table 1F Number of RP by years: recruitment of consultants

\begin{tabular}{|crrrr|}
\hline \multirow{4}{*}{ Year } & & \multicolumn{2}{c}{ Consultants } & \multirow{2}{*}{ Total } \\
\cline { 2 - 4 } & 2016 & No & Yes & \\
\cline { 2 - 4 } & 2017 & 19 & 10 & 23 \\
\cline { 2 - 4 } & 2018 & 43 & 26 & 69 \\
\cline { 2 - 4 } & 2019 & 9 & 15 & 24 \\
\hline & Total & $\mathbf{8 7}$ & $\mathbf{5 8}$ & $\mathbf{1 4 5}$ \\
\hline
\end{tabular}

If personal data are used in research, the procedure of their processing presupposes observance of ethical norms. Only 13 authors in their research followed this aspect (Table 1G). 
Table $1 G$ Number of RP by years: ethical norms followed

\begin{tabular}{|ccccc|}
\hline \multirow{4}{*}{ Year } & \multicolumn{3}{c}{} & \multicolumn{2}{c|}{ Ethical norms followed } & \multirow{2}{*}{ Total } \\
\cline { 2 - 4 } & & No & Yes & \\
\cline { 2 - 5 } & 2016 & 22 & 1 & 23 \\
\cline { 2 - 5 } & 2017 & 29 & 0 & 29 \\
\cline { 2 - 5 } & 2018 & 61 & 8 & 69 \\
\cline { 2 - 5 } & 2019 & 20 & 4 & 24 \\
\hline
\end{tabular}

Health education is included in the Standard of General Secondary Education in the domain of "Sport and Health" (National Standard for General Secondary Education, 2013). In the scope of the present study, the themes of the RP were initially combined into three components of the curriculum: "Individual and Society", "Social Environment in Time and Space" and "Activity".

The component "Social Environment in Time and Space" was the focus of most of the RP (59 authors). Similarly, this was also the most frequently researched component by years (Table 2 ).

Table 2 Number of RP by years and components

\begin{tabular}{|c|c|c|c|c|c|c|}
\hline \multirow{7}{*}{ Component } & \multirow{3}{*}{$\begin{array}{l}\text { Social Environmet in } \\
\text { Time and Space }\end{array}$} & \multicolumn{4}{|c|}{ Year } & \multirow{2}{*}{ Total } \\
\hline & & 2016 & 2017 & 2018 & 2019 & \\
\hline & & 2 & 10 & 34 & 13 & 59 \\
\hline & 2 Individual and Society & 4 & 7 & 10 & 2 & 23 \\
\hline & 3 Activity & 17 & 9 & 5 & 0 & 31 \\
\hline & 4 Learner/Specific data & 0 & 3 & 20 & 9 & 32 \\
\hline & Total & 23 & 29 & 69 & 24 & 145 \\
\hline
\end{tabular}

The research interest of the youth went far beyond the scope of compulsory topics of the school curriculum. From the set of all the RP, several were selected and an additional component 4 - "Learner/Specific Data" was created. This component included $32 \mathrm{RP}$, covering almost one quarter of the total number of RP.

Looking at the distribution of components into separate themes, the largest number of RP was for component 1 - "Social Environment in Time and Space", covering such themes as "Identifying Unfavourable Factors Affecting Physical Health of the Body" and "Health Care and Preventive Measures" (24 RP in total). For the component "Activity", 11 research works were carried out on the theme "Providing Beneficial Factors for the Physical Health of the Body" (Table 3). 
SOCIETY. INTEGRATION. EDUCATION

Proceedings of the International Scientific Conference. Volume III, May $22^{\text {th }}-23^{\text {th }}$, 2020. 424-436

Table 3 Number of RP by themes and components

\begin{tabular}{|lrrrrr|}
\hline \multirow{2}{*}{ Theme } & \multicolumn{3}{c}{ Component } & \\
\cline { 2 - 5 } & $\mathbf{1}$ & $\mathbf{2}$ & $\mathbf{3}$ & $\mathbf{4}$ & Total \\
\hline Medicine / Technology improvements & 0 & 0 & 0 & 2 & 2 \\
\hline Medicine / Health Improvement & 2 & 0 & 0 & 3 & 5 \\
\hline $\begin{array}{l}\text { Ethics of human action in modern society / Revision of ethical } \\
\text { norms }\end{array}$ & 0 & 0 & 1 & 0 & 1 \\
\hline Interest in a set of health and aesthetic parameters of the body & 3 & 1 & 0 & 2 & 6 \\
\hline $\begin{array}{l}\text { Identification of factors beneficial to physical and mental health of } \\
\text { the body }\end{array}$ & 10 & 1 & 1 & 1 & 13 \\
\hline $\begin{array}{l}\text { Identification of factors beneficial to the physical health of the } \\
\text { body }\end{array}$ & 6 & 2 & 1 & 1 & 10 \\
\hline Providing factors beneficial to the physical health of the body & 0 & 6 & 11 & 0 & 17 \\
\hline Identification of factors detrimental to physical health of the body & 12 & 4 & 5 & 4 & 25 \\
\hline Study of physical (biochemical) parameters of the body & 0 & 0 & 2 & 0 & 2 \\
\hline Knowledge of physical (genetic) parameters of the body & 0 & 0 & 1 & 0 & 1 \\
\hline Examination of physical (visual) parameters of the body & 1 & 0 & 1 & 1 & 3 \\
\hline Knowledge of physical parameters of the body & 6 & 1 & 4 & 4 & 15 \\
\hline Study of mechanisms of regulation of body functions & 0 & 0 & 0 & 1 & 1 \\
\hline $\begin{array}{l}\text { Investigation of mechanisms of bodily functions (memory } \\
\text { formation) }\end{array}$ & 1 & 0 & 0 & 0 & 1 \\
\hline Investigation of bodily functions (brain function) mechanisms & 0 & 0 & 0 & 1 & 1 \\
\hline Providing beneficial factors for body health & 0 & 0 & 1 & 0 & 1 \\
\hline Identification of genetic factors unfavorable to body health & 0 & 0 & 0 & 1 & 1 \\
\hline Health Care / Reproductive Health / Preventive Measures & 1 & 0 & 0 & 0 & 1 \\
\hline Health care & 1 & 0 & 0 & 0 & 1 \\
\hline Health care, preventive measures & 12 & 8 & 3 & 8 & 31 \\
\hline Providing health benefits & $\mathbf{5 9}$ & $\mathbf{2 3}$ & $\mathbf{3 1}$ & $\mathbf{3 2}$ & $\mathbf{1 4 5}$ \\
\hline & Total & 0 & 3 & 7 \\
\hline
\end{tabular}

COMPONENTS: 1 Social Environment in Time and Space; 2 Individual and Society; 3 Activity; 4 Learner/Specific Data

The keyword analysis of RP was performed for each of the above components. The following is the list of the most frequently used keywords (terms) in the component 1 ("Social Environment in Time and Space") by the authors of RP.

Alzheimer's, amalgam, amylase, antiperspirant, lighting, exchange, deflection, memory, refreshing, bacterium, whitening, non-alcoholic, insomnia, curd, breakfast, carrot, cigarettes, chips, computer, defect, deformity, deodorant, diastolic, dirol, beverages, elgydium, breathing, emulsifier, physical, florbol, air, meat, gamma, taste, gas, pearled, gum, hybrid, hypodynamic, HIV, yogurt, ionizing, belts, potatoes, legs, delicacy, kyphosis, kinesiological, caffeine, composite, correction, chewing, motion, quality, reading, lecithin, lordosis, bread, peak flow, wash, litter, tongue, sleepiness, sleep, microflora, microclimate, microorganisms, monitoring, spine, muesli, snacks, itch, occupation, fatigue, persistence, deviation, carbonic, orbit, habits, 
paste, bathing, mouse stumps, mold, feet, lactic acid, contamination, filling, palms, lungs, ankles, antiperspirant, pulse, dust, radiation, regime, hands, ligaments, sweetbread, compression, sprain, face, fungus, cheese, systolic, oxygen, scoliosis, race, perfume, fragrance, smoking, soy, spearmint, strength, pressure, radiation, posture, shooting, chocolate, tobacco, butterfly, taping, tape, room, pace, trauma, tritan, nutrition, perception, reservoir, waffle, goalkeeper, vegetarian, vegetarianism, environment

The relationship between the number of tokens and types (Figure 1) proves a general regularity - as the number of tokens (for all RP) increases, the number of types increases (Spearman correlation coefficient 0.818; statistical significance level 0.01 ; $\mathrm{p}<0.000$ (two-sided); $\mathrm{N}=111$ ). Most $\mathrm{RP}$ contain up to 7,000 word types and 2,500 word types.

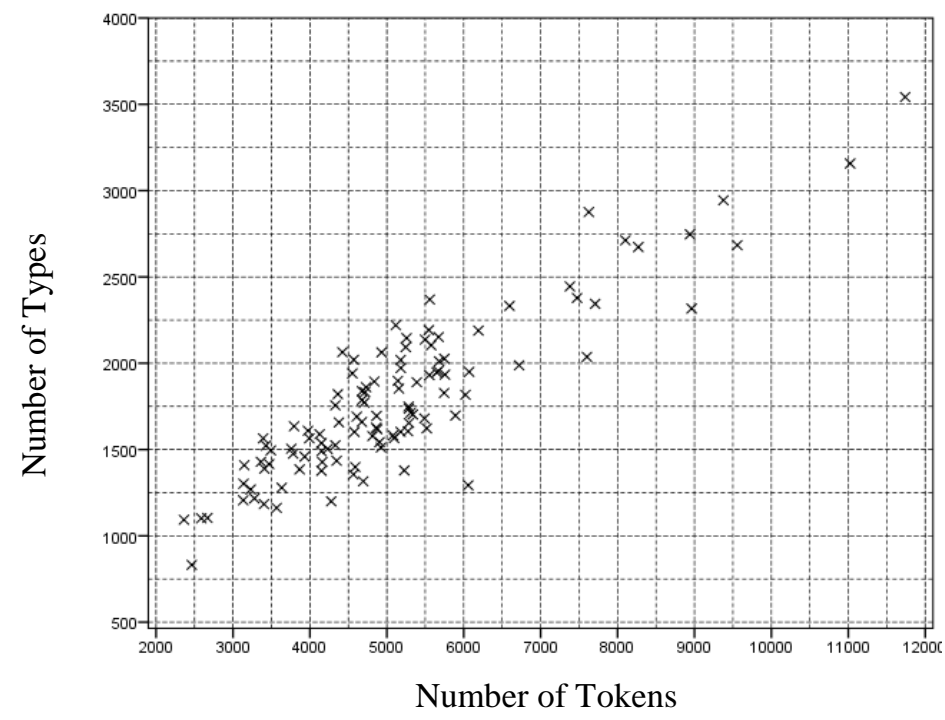

Figure 1 Relationship between the number of tokens and types

The relationship tokens/types (TTR) can be partially used to evaluate the lexical diversity of the language of RP, i.e., the variety of words and their derivatives (Jarvis, 2002). The histogram (Figure 2) shows that the frequency of the ratio types/tokens has a normal distribution (Shapiro-Wilk test: $\mathrm{p}=0.628$; $\mathrm{df}=111$; statistical significance level 0.05 ), with the mean of $35.68 \%$ and the standard deviation of 5.0184. Noteworthy are some of the lexically richest RP with relatively high TTR: 46-47\% (tokens only up to 4400) and RP with low TTR 21.3\% (tokens relatively high: > 6000). More lexically diverse RP are more comprehensive and nuanced in their description of the theme or problem being researched and are more exciting to read (Šišková, 2012).

The lexical diversity was analyzed using the Richards-Malvern method based on the calculation of the descriptive parameter (Malvern et al., 2004). Because the results obtained were stochastic, the calculations performed were time consuming and did not provide a sufficient differentiation in the evaluation 
of the lexical diversity of RP. In the case of the RP containing more keywords or numbers, the parameter values were lower.

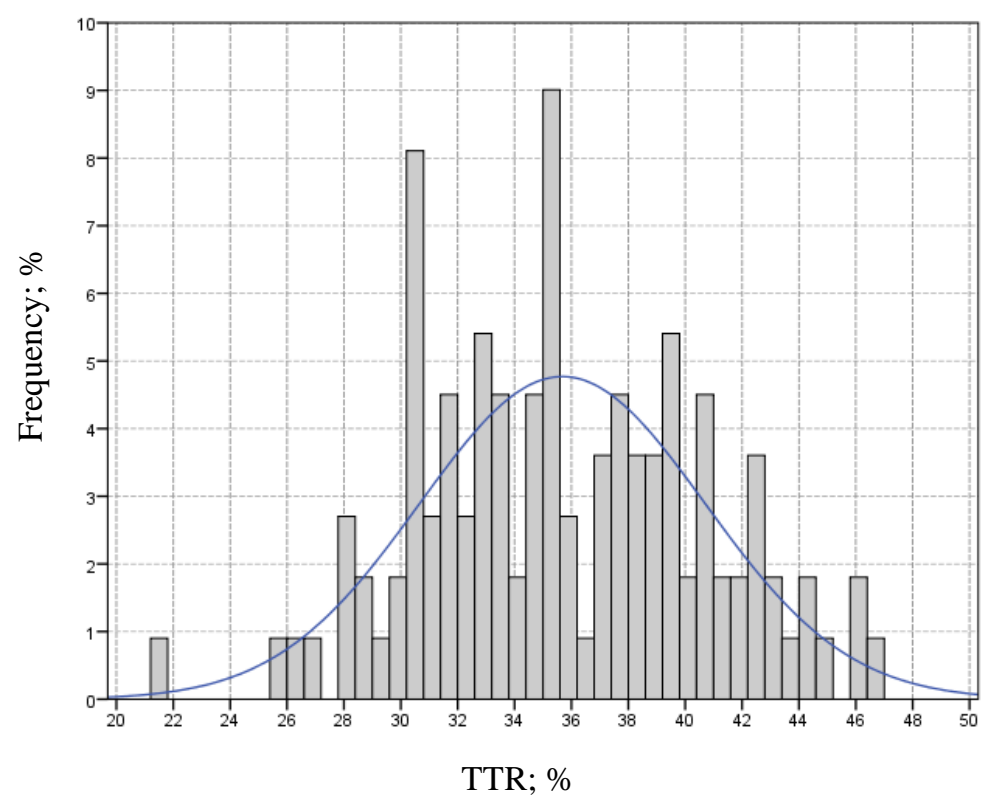

Figure 2 Histogram of TTR

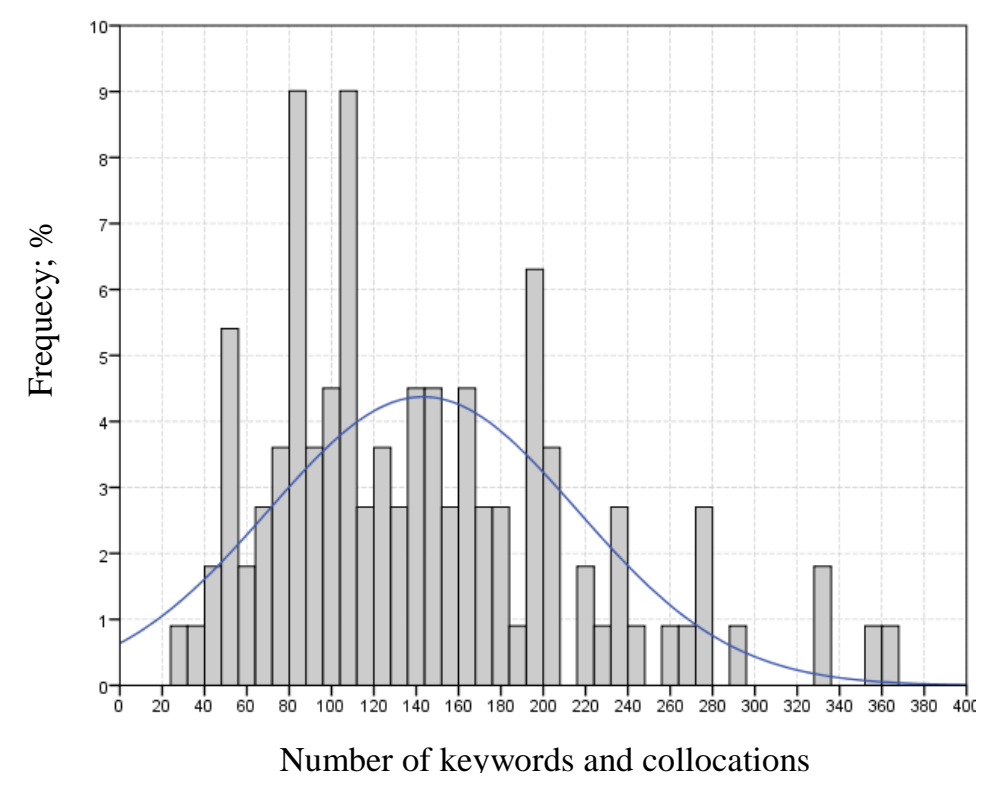

Figure 3 Histogram of keywords and collocations

AntConc software was used to find the keywords and collocations in RP. The entire set of the RP except the analysed one was used as a reference corpus. The keywords with their collocations (keyness) of each RP were determined by the logarithmic probability method ( $\mathrm{p}<0.01)$ (Gabrielatos, 2018). The histogram (Figure 3) shows the higher incidence of some keywords in RP (median 133). 
The relationship between key words/tokens and TTR (Figure 4) shows that there is no correlation $(-0.041 ; \mathrm{p}=0.670)$ that is statistically significant, and that the lexically diverse RP contained a relatively small proportion of keywords, and vice versa.

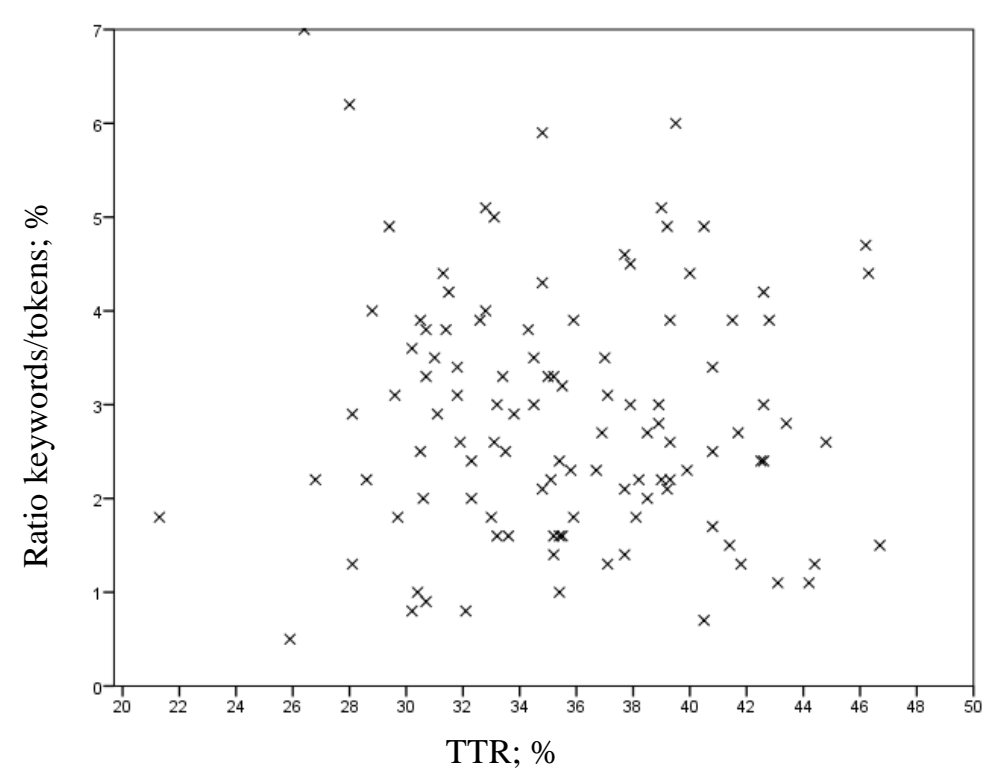

Figure 4 Relationship between the ratio keywords/tokens and TTR

The analysis resulted in a list of keywords (in bold) with the words associated with their collocations. The following are examples:

sheep / milk - suncream / sun - Angelman /syndrome - alcohol / beverage / usage lighting / measurement / norm - arthritis / diagnostic / treatment - blood / circulation - blood circulation / system - blood pressure / change - ascorbic acid / quantity - aspartam / use - fruits / vegetables - skin / care / type - ballet / ballet dancer - biorhythm / regulation / disorder breakfast / habit - cigarette / smoking - sugar / diabetes / level - chips / nutrition - deodorant / composition / characteristics - drink / refreshing - hearing / hygiene / disorder - breath / breathing - breathing / process / regulation - energy / drink - physical / health / activity / ability - taste / booster - glucose / concentration / level - pregnant / HIV positive - gum / chewing handball / handbolist - hypermobility / joint - hypodynamics / risk - homeopathy / efficacy exhalation / peak flow - calcium / reversal - contraception / agent / method - cosmetics / agent - color / recognition / vision / perception - breast / cancer - reading / speed - lecithin / soy / sunflower - balance / physical / activity - bread / taste / mold - pasta / product - tongue / anatomy / problem - sleep / apnea / disorder - barley / varieties / products - spine / strain mouth / cavity / rinse - music / listening - nitrate / concentration - fatigue / grade - norm / menu - orthodontics / service - overload / emotional - pectin / quantity - foot / strain / footprint - lactic acid / bacterium - finger / footprints - anti-inflammatory / drug / usage - teenager / physiology - dust / concentration - vision / sharpness / perception / defect - reittherapy / method - hand / lean / wash - bite / type / disorder - salt / volume / use - heart / rhythm - load / physical / influence - brain / structure - perfume / properties / usage / composition / influence - pressure / blood - sport / clothing - posture / analysis / disturbance / problem / improvement - shooting 
/ technique - temperature / body - tattoo / tattoo - tea / production / use - noise / level - diet / intake / type - vaccination / necessity - goalkeeper / game - vegan / nutrition - vegetarianism / concept / nutrition - wave / brain / delta - vitamin / D / quantity - tooth / anatomy / problem / whitening / paste / structure / health / cleaning

To find keywords throughout the RP corpus, a search for keyword morphemes or parts thereof was performed using AntConc. The most common (> 770) keyword morphemes (Figure 5) were: tooth, blood, physical, vitamin, load, nutrition, color, dig, sport, sugar, indicating a profound interest of learners in the themes.

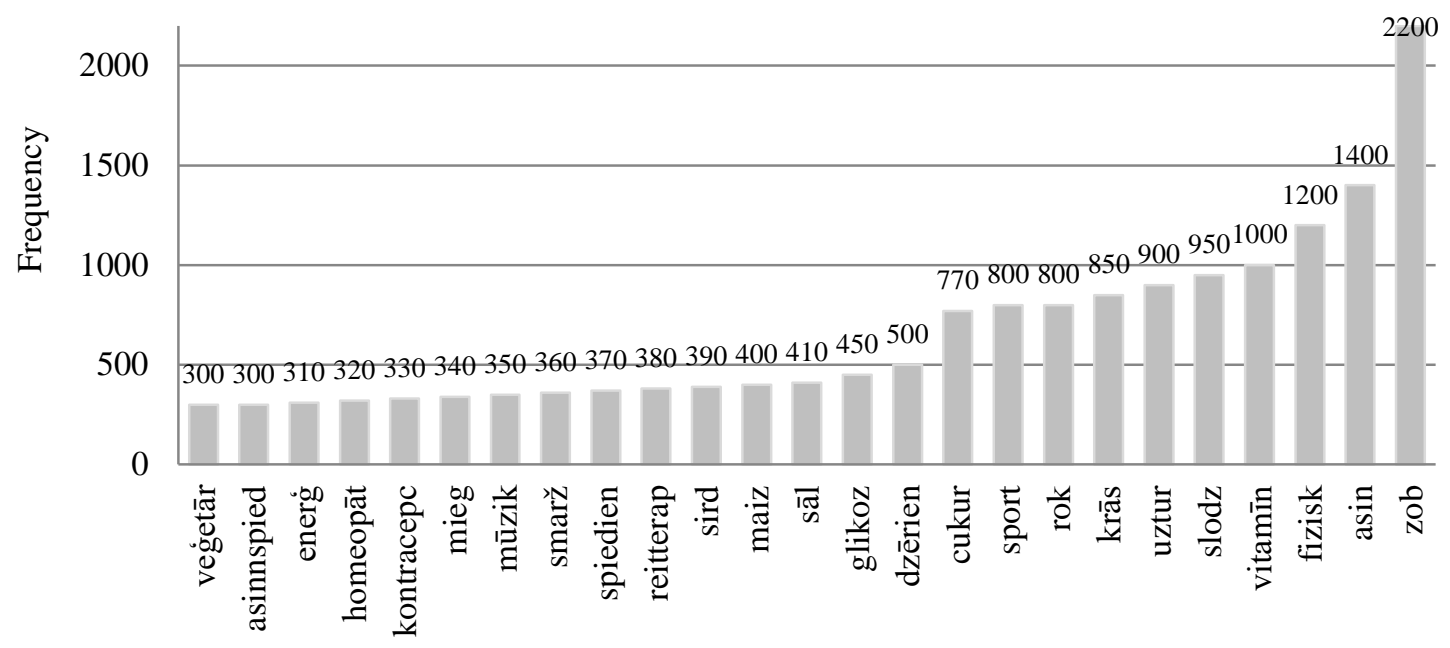

Figure 5 Frequency of keyword morphemes (in Latvian)

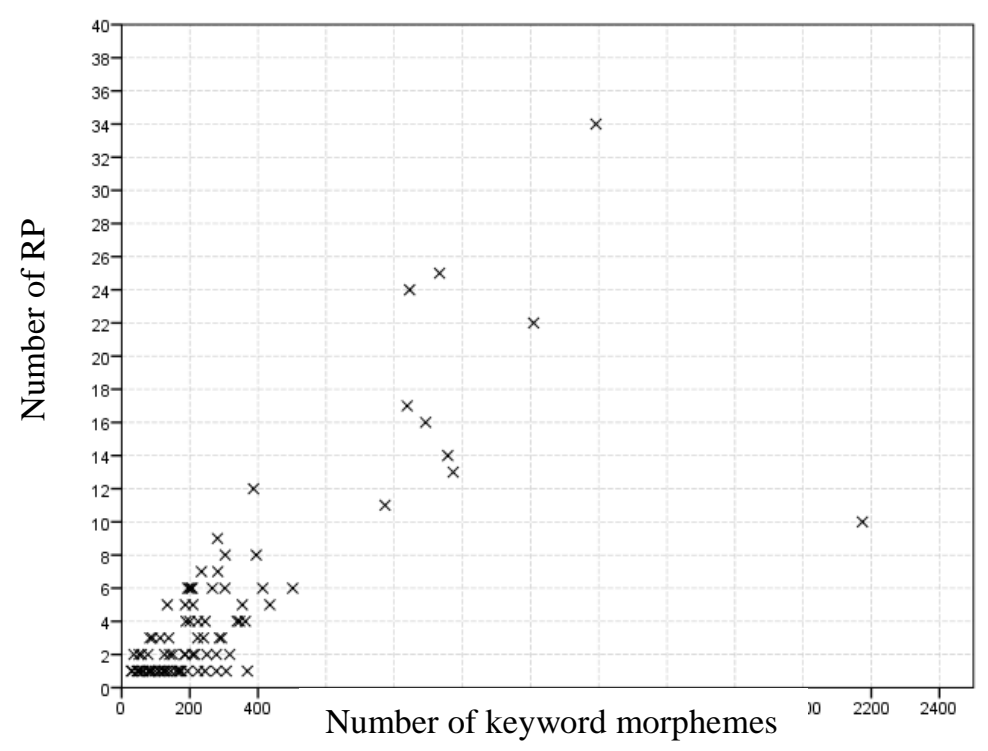

Figure 6 Relationship between the number of RP and keyword morphemes 
There is a statistically significant Spearman correlation between the number of RP and keyword morphemes (0.718; $\mathrm{p}<0.000 ; \mathrm{N}=87$ ) (Figure 6). This indicates a tendency for most of the RP to have single-keyword morphemes, i.e. several RP had similar themes.

\section{Conclusions}

The number of RP (increase in number) in Health Science developed over several years confirms high school learners' interest in the health issues of society, not only of their own and their peers, and their desire to maintain and improve their health. The themes chosen reflect the priority values of the young people, their interest and their willingness to pursue research.

The analysis of the RP is the basis for drawing serious conclusions about the high school learners' 'empowerment', the support they were given (or the teacher was unable to), and on purposefulness in data processing techniques, including errors that may not have occurred.

By using the corpus of high school learners' RP, RP can be categorized according to a variety of criteria: theme, use of keywords (terms), diversity and length of collocations, etc. Several results of the corpus analysis can be used as criteria for assessing RP.

The results of the present study show that the general statistical characterization of the language used in RP of Latvian high school learners in Health Science is different, i.e., they differ in terms of lexical diversity and the frequency of keywords used and their collocations. Mostly individual keywords dominate, which allows us to judge about a frequent thematic uniformity.

The results of the analysis indicate that the use of general and special language tools is not very successful, thus necessitating the improvement of the writing quality of RP.

The resulting corpus of RP of high school learners can be used both for general information on the thematic content of developed papers in Health Science and for the development of dictionaries and glossaries, which in turn could serve as recommendations for learners and teachers in future work on the development of RP both in the choice of themes and in the presentation of research.

\section{References}

Aizsila, A. (2012). Latvijas Lauksaimniecības universitātes sadarbība ar skolām. Proceeding of the International Scientifical Conference, Volume I, 24-33. Retrieved from https://pdfs.semanticscholar.org/dfb7/0b263825bdbbfca8443d208a615022e95aaa.pdf

Bañez, M.M., Sarmiento, M.B., \& Bañez, R.M. (2019). Cognitive models and literary competence of junior high school students. PUPIL: International Journal of Teaching, 
Education and Learning, 3(1), 258-280. Retrieved from https:/grdspublishing.org/ index.php/PUPIL/article/view/1947

Basch, C.E. (2011). Healthier students are better learners: a missing link in school reforms to close the achievement gap. Journal of School Health, 81(10), 593-598.

Begoray, D.L., Wharf-Higgins, J., \& Macdonald, M. (2009). High school health curriculum and health literacy: Canadian student voices. Global Health Promotion, 16(4), 35-42.

Elo, S., \& Kyngäs, H. (2008). The qualitative content analysis process. First published: 18March 2008. Leading Global Nursing Research, 62(1). Retrieved from https://onlinelibrary.wiley.com/doi/abs/10.1111/j.1365-2648.2007.04569.x

Gabrielatos, C. (2018). Keyness Analysis: Nature, Metrics and Techniques. In Taylor, C., Marchi, A. (Eds.), Corpus Approaches to Discourse: A critical review (pp. 225-258) Oxford: Routledge. Retrieved from

https://www.researchgate.net/publication/319208347_Gabrielatos_C_2018_Keyness_A nalysis_nature_metrics_and_techniques_In_Taylor_C_Marchi_A_eds_2018_Corpus_A pproaches_to_Discourse_A_critical_review_Oxford_Routledge_225-258

Jarvis, S. (2002). Short Texts, Best-fitting Curves and New Measures of Lexical Diversity Language Testing, 19(1), 57-84. Retrieved from https:/www.researchgate.net/profile/ Scott_Jarvis4/publication/278717839_Short_texts_best-tting_curves_and_new_ measures_of_lexical_diversity/links/55843b0308aeb0cdaddbb39a/Short-texts-besttting-curves-and-new-measures-of-lexical-diversity.pdf

Konu, A., \& Rimpelä, M. (2002). Well-being in schools: a conceptual model. Health promotion international, 17(1), 79-87.

Malvern, D., Richards, B., Chipere, N., \& Duran, P. (2004). Lexical Diversity and Language Development: Quantification and Assessment. Basingstoke: Palgrave Macmillan.

Ministru kabineta 2013.gada 21.maija noteikumi Nr.218” Noteikumi par valsts vispārējās vidējās izglītības standartu, mācību priekšmetu standartiem un izglītības programmu paraugiem”. Pieejams https://likumi.lv/ta/id/257229

Pace, M. (2017). Adapting literature to the language classroom. PUPIL: International Journal of Teaching, Education and Learning, 1(1), 01-12. DOI: https://doi.org/10.20319/ pijtel.2017.11.113

Peralta, L., \& Rowling, L. (2018). Implementation of school health literacy in Australia: A systematic review. Health Education Journal, 77(3), 363-376.

Skalberga, A. (2012). Vidusskolēna literārās kompetences veidošanās. Promocijas darbs. Rīga LU. 157. Pieejams https://dspace.lu.lv/dspace/bitstream/handle/7/4834/33573-Anita_ Skalberga_2012.pdf?sequence $=1 \&$ isAllowed $=y$

Stars, I. (2019). Pusaudžu veselībpratības konceptualizācija veselības izglītības diskursā. Promocijas darbs. Rīga, LU. 199. Pieejams https://dspace.lu.lv/dspace/bitstream/ handle/7/48881/298-72764-Stars_Inese_is14130.pdf?sequence=1\&isAllowed=y

Šišková, Z. (2012). Lexical Richness in EFL Students' Narratives - University of Reading, Language Studies Working Papers, Eds. Ciarlo C., D.S. Giannoni, Vol. 4, 26-36. Retrieved from https://pdfs.semanticscholar.org/a93b/a9b8f746800dc06ebeda02284cd 8148d238a.pdf

Valsts izglītības satura centrs. (2019). Vadlīnijas skolēnu zinātniskās pētniecības darbu izstrādei un vērtēšanai. Retrieved from https://visc.gov.lv/visc/projekti/dokumenti/ esf_8321/20191210_zpd_vadlinijas.pdf 